\title{
Larvae of Megaselia Rondani, 1856 (Diptera: Phoridae) as parasitoid of Sphingidae (Lepidoptera) and its frugivory on avocado
}

\author{
Thiago S. Souza ${ }^{1 \pm=0}\left(\mathbb{C}\right.$, Vinicius J. Fernandes ${ }^{1 \oplus}$, Elen L. Aguiar-Menezes ${ }^{2}{ }^{\oplus}$, André L. S. \\ Resende $^{2 \oplus}$, Thalles P. L. Pereira ${ }^{3 \oplus}$, Vinícius S. Gazal ${ }^{2 \oplus}$, Eurípedes B. Menezes ${ }^{2 \oplus}$
}

${ }^{1}$ Postgraduate Program in Crop Science, Federal Rural University of Rio de Janeiro, Rod. BR 465, 23897-000 Seropédica, RJ, Brazil. ${ }^{2}$ Department of Entomology and Phytopathology, Federal Rural University of Rio de Janeiro, Rod. BR 465, 23897-000 Seropédica, RJ, Brazil. ${ }^{3}$ Postgraduate Program in Zoology, University of São Paulo, Street of Matão, 05508-090 São Paulo, SP, Brazil.

拝=Corresponding author: thiagosampaio.agro@gmail.com

Edited by: Francisco J. S. Duque

Received: March 08, 2020. Accepted: July 29, 2020. Published: September 04, 2020.

\begin{abstract}
The members of the family Phoridae (Insecta: Diptera), whose adults are commonly known as scuttle fly or humpbacked fly, differ widely as to their feeding habits in the larval and adult stages. Dipteran larvae of Megaselia Rondani, 1856 (Diptera: Phoridae) vary considerably in feeding habits. The results of this study confirm the parasitic and frugivorous habits of Megaselia larvae. Megaselia scalaris (Loew, 1866) behaved as primary parasitoid of Isognathus caricae (Linnaeus, 1758) (Lepidoptera: Sphingidae) larvae in confinement using cage under laboratory conditions. It is also the first time the frugivorous habit of $M$. scalaris larvae is recorded in ripe fruits of the avocado tree (Persea americana, Lauraceae) under field conditions.
\end{abstract}

Keywords: Scuttle flies, Parasitoid-host relationship, Hawk moth, Fruit-eating habit, Persea americana.

The Phoridae (Insecta: Diptera) family is a large dipteran group, with 4,081 species distributed in 289 genera present in all biogeographic regions of the world (Pape \& Thompson 2020) and in Brazil about 851 species are known (Ament \& Pereira 2020). The scuttle flies differ widely as to their feeding habits in the larval and adult stages (Disney 1990, 1994; Disney et al. 2010). They can be scavengers, associated to fungi, herbivores, predators and parasitoids and in some cases causers of human myiasis (Disney 1994; Brown 2009). These different habits of the scuttle flies contribute to ecosystem dynamic because they can fulfill different ecological services. In agriculture, some species of Megaselia Rondani, 1856 (Diptera: Phoridae) are crop pests or cause damage with potential economic losses to beekeeping (Lee \& Disney 2004; Owens et al. 2016). Megeselia scalaris (Loew, 1866) is cosmopolitan species and had already been reported as parasitoids of immature forms of pest species of the family Noctuidae (Lepidoptera) in agricultural crops (Chacón De Ulloa \& Rojas De Hernandez 1981; Tefera 2004; Ruíz-Nájera et al. 2007; Berta et al. 2009).

The aims of this study were to report the parasitism of $M$. scalaris in Isognathus caricae Linnaeus, 1758 (Lepidoptera: Sphingidae) and the fruit-feeding behavior of $M$. scalaris larvae in Persea americana Mill. (Lauraceae).

In 2015, caterpillars of the Sphingidae family were observed defoliating Allamanda cathartica L., 1771 (Apocynaceae) on the outdoor garden of Central Pavilion of the Federal Rural University of Rio de Janeiro (UFRRJ), campus of Seropédica, RJ, Brazil $\left(22^{\circ} 45^{\prime} \mathrm{S}\right.$, $43^{\circ} 41^{\prime} \mathrm{W}, 33 \mathrm{~m}$ a.s.l.). Seventeen caterpillars of different instars were brought to the Integrated Center for Pest Management (CIMP)/UFRRJ laboratory and reared in a $30 \mathrm{~cm} \times 30 \mathrm{~cm} \times 30 \mathrm{~cm}$ voile fabric lined cage, using leaves of $A$. cathartica as food (Fig. 1). The leaves were provided attached to the twigs which were wrapped in moistened towel paper to their turgor pressure.

After obtaining adults, they were identified as belonging to the $I$. caricae species based on Miranda (2019). The species M. scalaris had been known to parasitize other species of Sphingidae (Souza et al. 2019), to assess whether they can parasitize I. caricae, on May 7, 2015, the immature stages ( 3 caterpillars and 2 pupae) and one adult of $I$. caricae were offered to $M$. scalaris adults obtained from the laboratory rearing kept at CIMP. Each stage was separately offered to the scuttle flies in a reared $30 \mathrm{~cm} \times 30 \mathrm{~cm} \times 30 \mathrm{~cm}$ voile fabric lined cage [1 cage with $20 \mathrm{M}$. scalaris adults (undetermined sex) per stage]. After 7 days of exposure to M. scalaris, I. caricae individuals were removed from the cages and individually separated in 1-L transparent plastic containers, sealed with a perforated plastic lid and covered with PVC film. The caterpillars were fed with leaves of $A$. cathartica and the adult, with a solution of honey offered in cotton wool during all experimental period. Between the 21st and 22nd days after the individualization of caterpillars, one of them died and $M$. scalaris adults emerged from other two caterpillars. A total of 101 parasitoids emerged from one caterpillar (46 males and 55 females) and 18 from the other ( 8 males and 10 females). After 20 days of moth pupae individualization, there was the emergence of an I. caricae adult and the other pupa was under observation for a period of 3 months, but there was no emergence of parasitoids. The I. caricae adult exposed to $M$. scalaris did not survive a few days after individualization and was also observed for 3 months, but there was no emergence of parasitoid. This result showed that $M$. scalaris behave as primary parasitoid of $I$. caricae larvae.

We observed Phoridae adults emerging from ripe and healthy (with no apparent injuries caused by arthropod or plant pathogens) fruits of the avocado tree (P. americana) in the district of Manuel Duarte, Rio das Flores, state of Rio de Janeiro, Brazil $\left(22^{\circ} 10^{\prime} 44^{\prime S}, 43^{\circ} 35^{\prime} 9^{\prime \prime} \mathrm{W}\right)$. Twenty four ripe and healthy fruits of $P$. americana were collected at the Seropédica campus of UFRRJ to better understand the phorids interaction with the avocado. The fruits were taken to the CIMP laboratory and distributed in three voile fabric lined cages of $30 \mathrm{~cm} \mathrm{x}$ $30 \mathrm{~cm} \times 30 \mathrm{~cm}$ (8 fruits/cage), with two white sheets and newspaper at the bottom, and kept in conditions of room temperature, humidity 
and light. After three days, dipterous larvae were observed on the skin of fruits. Over time, the fruit peel naturally broke, exposing the pulp on which the presence of fly pupae was observed.

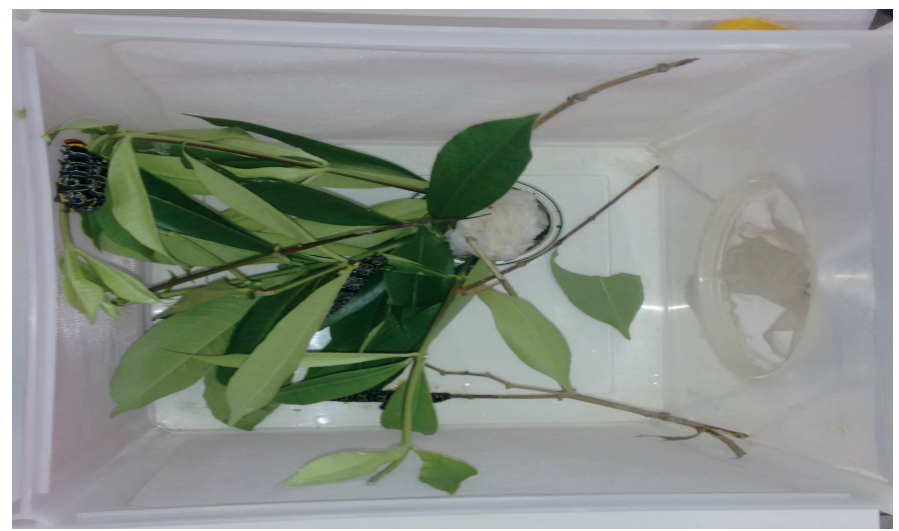

Figure 1. Rearing cage of caterpillars on leaves of Allamanda cathartica in the laboratory.

Phoridae adults appeared 14 days after the collection of the fruits and some individuals were placed in a $30-\mathrm{mL}$ glass vial containing $90 \%$ alcohol for specific identification. All Phoridae adults were identified as $M$. scalaris using morphological characters following the Borgmeier (1962) key. Insects identified were deposited at the Entomological Collection Costa Lima (Coleção Entomológica Costa Lima - CECL) (number record: 12509). We also conducted a laboratory rearing of this lineage of specimens of M. scalaris for seven months (xi.2014-v.2015), using avocado fruits, paper towel crushed and moistened with water and honey supplied in drops placed on the walls of the trays cover with PVC film.

This result showed other way to rear this scuttle fly in the laboratory, but further study is necessary to evaluate the viability of this methodology. As cited by Varney \& Noor (2010), M. scalaris is used as an experimental species in genetics, biology, and drug and pollutant bioassay studies once it is readily cultured in the laboratory. Chakraborty et al. (2016) observed that M. scalaris (Bhavnagar strain) showed different growth patterns and biomass accumulations when reared in three different media [general Drosophila Fallen, 1853 medium, enhanced Drosophila medium, and SMS (soy milk SiO2) medium] in small culture jars at constant temperatures of $27 \pm 3^{\circ} \mathrm{C}$, relative humidity of $35 \pm 5 \%$, and photoperiod of 12:12 (L:D) hours, and they concluded that larvae grow maximally in the SMS medium.

However, since $M$. scalaris is considered an omnivorous species and its larvae can feed on fresh or decaying fruits (Disney 2008), a further study of this scuttle fly as a possible pest of avocado trees can bring new views on the agricultural importance that this species may have, in addition to economic impacts in avocado production. Currently only Stenoma catenifer Walsingham, 1912 (Lepidoptera: Elachistidae), Aspidiotus destructor Signoret, 1869 (Hemiptera: Diaspididae) and Anastrepha striata Schiner, 1868 (Diptera: Tephritidae) are known as insect pests of avocado in Brazil (Reis \& Souza 1982; Nava et al. 2006; Zucchi et al. 2011).

\section{Acknowledgments}

The scholarship grant to first, second and fifth authors by the Coordination for the Improvement of Higher Education Personnel (CAPES) is gratefully acknowledged - Finance Code 001.

\section{Authors' Contributions}

TS Souza and VJ Fernandes conceived the study. TS Souza, ALS Resende and VS Gazal wrote the first version of the manuscript. EB Menezes, EL Aguiar-Menezes and TPL Pereira reviewed the manuscript and made improvements to it. TPL Pereira identified the insect. All authors read and approved the manuscript.

\section{References}

Ament, D. C.; Pereira, T. P. L. (2020) Phoridae in Catálogo Taxonômico da Fauna do Brasil. PNUD. http://fauna.jbrj.gov.br/fauna/ faunadobrasil/183530. Access on: 30.vii.2020.

Berta, D. C.; Colomo, M. V.; Valverde, L.; Sueldo, M. R.; Dode, M. (2009) Aportes al conocimiento de los parasitoides de larvas de Noctuidae (Lepidoptera) en el cultivo de soja en Tucumán, Argentina. Acta Zoológica Lilloana, 53: 16-20.

Borgmeier, T. (1962) Versuch einer Uebersicht ueber die neotropischen Megaselia- Arten, sowie neue oder wenig bekannte Phoriden verschiedener Gattungen (Diptera, Phoridae). Studia Entomologica, 5: 289-488.

Brown, B. V. (2009) Manual of Central American Diptera: Volume 1. Ottawa: NRC, Research Press.

Chacón De Ulloa, P.; Rojas De Hernandez, M. (1981) Biologia y control natural de Peridroma saucia, praga de la flor de la curuba. Revista Colombiana de Entomología, 7: 47-53.

Chakraborty, A.; Naskar, A.; Parui, P.; Banerjee, D. (2016) Developmental variation of Indian thermophilic variety of scuttle fly Megaselia (Megaselia) scalaris (Loew, 1866) (Diptera: Phoridae) on different substrates. Scientifica, article ID 4257081: 1-9. doi: $10.1155 / 2016 / 4257081$

Disney, R. H. L. (1990) Some myths and the reality of scuttle fly biology. Antenna, 14(2): 64-67.

Disney, R. H. L. (1994) Scuttle Flies: The Phoridae. London: Chapman \& Hall.

Disney, R. H. L. (2008) Natural history of the scuttle fly, Megaselia scalaris. Annual Review of Entomology, 53: 39-60. doi: 10.1146/ annurev.ento.53.103106.093415

Disney, R. H. L.; Taylor, S. J.; Slay, M. E. (2010) Review of the scuttle flies (Diptera: Phoridae) recorded from caves in the USA, with new records from Arkansas and Missouri. Subterranean Biology, 7: 7596. doi: 10.3897/subtbiol.8.1233

Lee, H. S.; Disney, R. H. L. (2004) A new species of Megaselia (Diptera: Phoridae) attacking a wasp and a bee (Hymenoptera: Vespidae, Eumeninae and Megachilidae) in South Korea. Fragmenta Faunistica, 47(1): 81-87. doi: 10.3161/00159301FF2004.47.1.081

Miranda, F. C. (2019) Lepidoptera brasilienses - Lepidopterofauna Neotropical. http://www.lepidoptera.datahosting.com.br/. Access on: 8.iii.2019.

Nava, D. E.; Parra, J. R. P.; Bento, J. M. S.; Diez-Rodriguez, G. I.; Haddad, M. L. (2006) Distribuição vertical, danos e controle cultural de Stenoma catenifer Walsingham (Lepidoptera: Elachistidae) em pomar de abacate. Neotropical Entomology, 35(4): 516-522. doi: 10.1590/S1519-566X2006000400015

Owens, D.; Nuessly, G. S.; Beiriger, R.; Larsen, N. (2016) Cob flies, Megaselia spp. (Diptera: Phoridae), in sweet corn. Gainesville: University of Florida/IFAS Extension, 1-5, ENY-754. https://edis.ifas. ufl.edu/pdffiles/IN/IN114400.pdf. Access on: 08.iii.2019

Pape T.; Thompson F. C. (2020) Systema Dipterorum (version 2.0, Jan 2011). In: Roskov Y.; Ower G.; Orrell T.; Nicolson D.; Bailly N.; Kirk P. M.; Bourgoin T.; DeWalt R. E.; Decock W.; Nieukerken E. van; Penev L. (Eds), Species 2000 \& ITIS Catalogue of Life - Digital resource. www.catalogueoflife.org/col. Access on: 31.vii.2020

Reis, P. R.; Souza, J. C. (1982) Pragas do abacateiro. Informe Agropecuário, 8: 77-79.

Ruíz-Nájera, R. E.; Molina-Ochoa, J.; Carpenter, J. E.; EspinosaMoreno, J. A.; Ruíz-Nájera, J. A.; Lezama-Gutiérrez, R.; Foster, J. E. (2007) Survey for hymenopteran and dipteran parasitoids of the fall armyworm (Lepidoptera: Noctuidae) in Chiapas, Mexico. Journal of Agricultural and Urban Entomology, 24(1): 35-42. doi: 10.3954/1523-5475-24.1.35

Souza, T. S.; Aguiar-Menezes, E. L.; Resende, A. L. S.; Pereira, T. P. L.; Gazal, V. S. (2019) Megaselia Rondani (Diptera: Phoridae) larvae as a Sphingidae (Lepidoptera) parasitoid. Arquivos do Instituto Biológico, 86: 1-3, e0812018. doi: 10.1590/1808-1657000812018

Tefera, T. (2004) Lepidopterous stem borers of sorghum and their natural enemies in eastern Ethiopia. Tropical Science, 44: 128-130. 
doi: $10.1002 /$ ts.153

Varney, R. L.; Noor, M. A. (2010) The scuttle fly. Current Biology, 20(11): R466-R467. doi: 10.1016/j.cub.2010.03.043

Zucchi, R. A.; Silva, R. A.; Deus, E. G. (2011) Espécies de Anastrepha e seus hospedeiros na Amazônia brasileira. In: Silva, R. A.; Lemos, W. P.; Zucchi, R. A. (Eds.), Moscas-das-frutas na Amazônia brasileira: diversidade, hospedeiros e inimigos naturais, pp. 51-70. Macapá: Embrapa Amapá. 